\title{
Linking Public Administration to Comparative Politics
}

\author{
Herbert H. Werlin
}

magine students of comparative politics giving their professors the following examination questions:

1. Why is it that autocratic governments are sometimes more effective in promoting development than their more democratic counterparts?

2. Why is it that More Developed Countries (MDCs) are both more centralized and more decentralized than Less Developed Countries (LDCs)?

3. Why is it that corruption is devastating for poor countries, but not rich countries?

4. What explains the capacity of countries to change their culture?

5. Why is economic globalization good for the development of some countries, but not for others?

Judging by a survey of recent comparative politics textbooks, one group of professors might begin their answers with a description of political systems (authoritarian, totalitarian, democratic, single-party, multiparty, parliamentarian, presidential, federal, military, etc.); another would introduce a variety of

Herbert Werlin is an independent consultant in College Park, Maryland (werlin@crosslink.net). He retired from the University of Maryland's urban studies department in 1993. For many years, he did research, writing, and editing for the World Bank, from which his 1998 book emerged. He has taught political science in various universities, most recently for the University of Maryland's Senior University. His first book on the Nairobi City Council stemmed from a 1966 political science dissertation completed at the University of California, Berkeley. concepts (conflict, choice, structure, function, culture, participation, attitudes, values, processes, opinions, rationality, etc.). I believe the professors in both groups would fail to provide satisfactory answers because they would neglect public administration. While the professors might discuss the selection of leaders (who governs?) and policies (rational or irrational choice), they would tend to ignore issues like the quality of government and the implementation of policies.

Herman Finer, who introduced me to comparative politics during the early 1950 s at the University of Chicago, never made a distinction between the study of political science and public administration. Over the years, however, the two subjects have clearly become distinct objects of study. Hull $(1999,122)$ found that only $1 \%$ of the articles published in Comparative Politics, Comparative Political Studies, and World Politics between 1982 and 1997 were primarily concerned with administration. Robert Bates, in his 1996 APSA-CP Newsletter summary of the contributions of comparative politics literature to modernization theory, failed to include public administration as an important component of this literature. Lichbach and Zuckerman (1997), in their comprehensive review of recent comparative politics literature, also failed to consider public administration research.

In my view, comparativists ignore the findings of public administration scholars for three reasons. First, quantifying the objects of public administration is difficult. Second, many view public administration as a "technical subject" without political significance. Third, and most impor- tantly, many do not understand or acknowledge the political nature of administration. This aversion is regrettable and indefensible, however, if one accepts the classical definition to be "the relationship of leadership to followership for the purpose of governance" (Wolin 1960, 66) and public administration to be "the art and science of governance" (Waldo 1980, 75).

\section{Political Elasticity (PE) Theory}

In a recent book (Werlin 1998), I developed a theory of development I dubbed "political elasticity" that permits equal consideration of political science and public administration. Political elasticity theory includes five major propositions.

1. The more governments or those in authority can integrate and alternate soft forms of political power (linking incentives to persuasion) with hard forms of power (including disincentives and coercion), the more effective they will be.

2. As leaders integrate and alternate soft and hard forms of power, their political power takes on "rubber band" and "balloon" characteristics, allowing them to (a) decentralize or delegate power in various ways without losing control and (b) expand their influence reliably, thereby predictably affecting the behavior of wider circles of citizens, participants, and subordinates.

3. Political elasticity depends partly on the selection of appropriate political hardware (including "objective" forms of 
organization, regulation, procedure, and technology) but mostly on the selection of political software (i.e., policies and practices that foster respectful relationships between leaders and followers).

4. The effectiveness of political software is directly proportional to governmental success in establishing acceptable goals, hiring qualified personnel, encouraging training, delegating responsibility, stimulating motivation and competition, paying attention to morale, expanding two-way flows of communication, promoting legitimacy, maintaining supervision, cultivating contractors, protecting independent spheres of authority, and developing conflict resolution procedures. Inasmuch as a government fails to do any of these things (with appropriate variations), its efforts to reform both micro-and macroadministration are going to be problematic.

5. Enhancing political software requires a balancing of the two forms of struggle-for competitive advantage and for consensus-suggested by Wolin (1960, $10,363)$. Within the framework of the definition of politics I gave above, measures taken to increase advantage may be considered "primary politics" and measures taken to build consensus may be considered "secondary politics."

In what follows, I employ the principles of political elasticity theory to answer some of the "student questions" listed at the beginning of this article. In doing so, I will focus on the countries that underscore the "mysterious" characteristics of development.

\section{The Netherlands: Combining Centralization with Decentralization}

The propositions associated with PE theory overcome the centralization/decentralization dichotomy by suggesting that under political elasticity, forms of decentralization can be expanded without reducing centralization; under political inelasticity, leaders fear decentralization, thereby weakening their implementation capacity; under political elasticity, various forms of decentralization and centralization merge; and under political inelasticity, forms of decentralization and centralization tend to be so ineffective as to be meaningless. The Netherlands is a good example of a politically elastic state whose development authorities have pursued decentralization without reducing centralization.

The Netherlands would appear to be one of the world's most planned and controlled countries, with building regulations covering everything from a structure's location within a plot and its relation to surroundings to the color of the paintwork and choice of materials (Davies 1988, 211). It would also appear to be a highly centralized country, with specific and general grants making up nearly $90 \%$ of local government revenue and with crown-appointed burgomasters and governors (Netherlands Scientific Council 1990, 197).

Yet, the Netherlands is also "a decentralized state in which the municipalities have considerable autonomy" (Davies 1988, 220). Within limits set by central and provincial officials, each municipality prepares its own plans and regulations, following extensive discussions, negotiations, and opportunities for objection. Central government officials see their duty to be giving guidance without excessively interfering in local decision making (Hamnett 1985, 27).

Within the democratic Dutch system, national agencies seek the support of local governments to increase their budgets, and vice versa (Toonen 1987, 124). While Dutch provinces and municipalities guard their autonomy jealously, urban planners realize that, without national direction and legislation, "plans are just so much paper"

(Morris 1985, 65). Consequently, intergovernmental relations in the Netherlands require "specific provisions for coordination, negotiation, conflict resolution, consensus, and coalition building to enable parties to deal with their diverse and sometimes conflicting interests and relationships"

(Toonen 1987, 126).

Similarly, while the responsibility for Dutch housing, education, and social services has largely rested with church or private organizations, the government influences the content and delivery of these services by issuing various regulations, subsidies, and grants. Central government officials have also increasingly used block grants to municipal and provincial governments to enable them to exercise greater control over this system. Consequently, "decentralization now provides a means for extending and indeed strengthening central, national control over local housing corporations, but in indirect ways which do not appear to jeopardize their long-established ideological, legal and political independence" (Flynn 1986, 618).

The Dutch intergovernmental system is in a constant state of reconsideration and reform, according to a 1996 article by Toonen. As church or private organizations have encountered increasing problems with delivering services since the 1960s, more responsibility has been assumed by local and regional levels of government. While various reform proposals have been made or attempted (e.g., direct election of mayors and provincial governors), the central government continues to provide guidance and control. Yet, "ample opportunities exist to challenge, modify and even redefine and renegotiate national decisions at var- 
ious levels of government" (Toonen 1996, 619).

\section{Egypł}

In contrast to the Netherlands, Egypt exemplifies a politically inelastic state whose leaders' fear of losing their control through decentralization has actually lessened their ability to implement positive changes. During the 1970s, with President Sadat's support, the U.S. Agency for International Development granted funds to villages for undertaking agreed-upon infrastructure development programs (Chetwynd and Samaan 1984). This project was terminated as a result of increasing centralization under President Mubarak. In 1994, village elections of leaders were discontinued in the face of a rise in Islamic fundamentalism and related fears of rural political instability. Consequently, "Egypt's bureaucratic-authoritarian regime remains highly centralized and impervious to serious challenge within the existing institutional system" (Tschirgi 1999, 29).

Since local governments are weak, they are dependent on taxes administered by the Ministry of Finance. However, "political inelasticity" (when political power lacks rubber band or balloon characteristics) now prevails, marked by unwieldy organizational structure, inefficiency, overstaffing, poor working conditions, low salaries, employee apathy, lack of coordination and communication among and within agencies, and corruption (Al-Sayyid 1993). This accounts for the government's failure to improve living conditions, particularly in the rural areas, where about half the population are somewhat impoverished (Kienle 1998, 223). Overcentralization of government, together with an inefficient bureaucracy, enables affluent landowners, who benefit most from public works, to largely escape payments of land, building, and vehicle taxes, making cost-recovery and, thereby maintenance, very difficult. According to Tschirgi (1999), much of the recent terrorist campaign experienced by Egypt results from this situation rather than from religious fanaticism.

\section{BULLETIN BOARD}

\section{Council on Undergraduate Research to Expand to All the Social Sciences}

The Council on Undergraduate Research (CUR) promotes collaborative research by faculty and undergraduate students on the principle that research-active faculty members are better educators, and that students learn best by doing. At the June 2000 CUR national conference and General Council meeting, the CUR Council voted to establish a Social Sciences Division as soon as a critical mass of people express interest in joining such a division. We anticipate that the division will be created formally in June 2001. Individual CUR members are currently being asked to affiliate with the new division, and applications are being sought from a minimum of 12 individuals to run for positions as CUR councilors from the Social Sciences Division.

CUR began as an organization for chemists from primarily undergraduate colleges. Over the years, it has been expanded to include divisions for chemistry, biology, geosciences, mathematics/computer science, physics/astronomy, psychology, engineering, and at large.

While CUR admits individual members from any field of study, only psychology among the social sciences has had its own division. Others from the social sciences and humanities had a "home" in the At Large Division, which also contains college administrators. Divisions are important because CUR is a democratic, grassroots organization, and programs are developed through the volunteer work of division members. Disciplinary programming includes special web pages, sessions at national meetings, and articles in CUR Quarterly, a journal for issues related to research by faculty and students at primarily undergraduate institutions.

CUR welcomes faculty and administrators from all types of colleges and universities as members, but the central focus of the organization-and hence its meetings, publications, and government relations program - is on primarily undergraduate institutions and institutions with particular concern for undergraduate research.

The CUR Meetings Committee has chosen "Undergraduate Research for All Students" as the tentative theme for CUR 2002, which will be held at Connecticut College. This theme will allow immediate participation by social scientists. Possible workshop topics include assessment, community-based research, interdisciplinary research, undergraduate research in the social sciences, and undergraduate research for future educators.

CUR runs a series of small meetings called CUR Institutes on such topics as "The Vital Faculty: Issues After Tenure," "Institutionally Undergraduate Research," and "Grant Writing." These Institutes have always included participation by social scientists and faculty members in the humanities. But now, the organization looks forward to adding social scientists of all kinds to its consultants and speakers programs.

If you are interested in learning more about CUR, visit www.cur.org or contact Julie Watson at 202-783-4810 or curmember@cur.org. 


\section{Japan: Development Despite Corruption}

When analyzing corruption, I find it useful to make a distinction between primary and secondary corruption, based upon my dichotomy of primary and secondary politics. Primary corruption involves excessive partisan behavior (amounting to greed) that is subject to official punishment or popular condemnation. In most cases, fear and shame are associated with primary corruption. Secondary corruption, on the other hand, is partisan behavior that is carried out in the absence of viable statesmanship or governance. Those engaged in secondary corruption have little fear of punishment or concern about dishonor or disgrace.

While primary corruption does not necessarily prevent development, secondary corruption corrodes and weakens the political software needed to foster development. In so doing, it causes or intensifies political inelasticity. To use an analogy, corruption is a fever that weakens the political system. In an MDC such as Japan, there are various means for controlling the fever. Thus, while "bribery is built into Japanese politics" (Iga and Auerbach 1977, 556), Japan continues to be "one of the fastest growing industrial economies ever known" (Johnson 1995, 202). (The short comparison with Sierra Leone that follows is intended to illustrate the difference between primary and secondary corruption.)

The Japanese have an elaborate system of gift giving, which clearly affects the political process. Most Japanese politicians, according to van Wolferen $(1989,134)$, are tied into a system of contracts and favors. When a Diet member helps someone obtain a government or private-sector contract, the beneficiary is expected to pay the politician or political faction at least $10 \%$ of the total price of the contract, and sometimes as much as $20 \%$. This is one reason why the Japanese spend four times more per capita on politics than people in any other industrialized nation (see Johnson 1995, 215).

In Japan, there is "a pervasive and institutionalized system of bidrigging" in the construction industry (Woodall 1993, 297). This dango system involves secret deals or joint ventures, brokers who arrange for the division of spoils, the hiring of retired officials, and gift giving to politicians willing to lubricate the appropriate bureaucratic and political wheels. Despite criticism in the press, the system is defended by top politicians on the grounds that they see nothing "wrong with bid-rigging that helps the construction industry operate smoothly and secures jobs" (Johnson 1995, 216).

Johnson (1995) has suggested that Japanese corruption is also fostered by the amakudari system, under which retired officials are allowed to take important positions in the legislature, local governments, banks, corporations, and construction companies. Indeed, one reason Japanese ministries failed to prevent widespread bankruptcies during the second half of the 1990s was because amakudari considerations compelled them to give preferential treatment to certain financial institutions (Inoguchi 1997, 95).

Various factors, however, combine to minimize the impact of corruption on the Japanese economy. Among the most important of these is the competence and integrity of the civil service. Upper-level civil servants are carefully selected, largely from among the graduates of Tokyo University's law school, and only about half of the candidates actually receive appointments. As such, they are "an elite of the elite" (Campbell 1989, 115). Those who survive the competitive process to get into the civil service, particularly into such ministries as Finance and International Trade and Industry (MITI), "tend to be among the best that Japan's educational system has to offer to that country's perspective employers" (Koh 1989, 253).

While the Japanese tend to be very tolerant of influence-peddling by politicians, they react strongly to evidence of dishonesty within their meritocratic public bureaucracy. Johnson $(1995,214)$, who found ample evidence of corruption in certain ministries or agencies, saw it as relatively absent from such sectors as the environment, foreign affairs, science and technology, economic planning, and justice. MacDougall concluded his analysis of the Japanese reaction to the Lockheed scandal with the observation that, despite Japanese tolerance of political impropriety, "clear violations of the law, personal enrichment through dishonest behavior, bureaucratic corruption, and unseemly behavior by national leaders ... are seen by the public as detrimental to legitimate government" $(1998,227)$.

While top-level civil servants consider their incomes to be between a half and two-thirds of what their peers in private firms are making, the frequency of corruption among Japanese civil servants, according to the National Personnel Authority, is remarkably low (Koh 1989, 223). Whereas in 1960, 6 of every 10,000 civil servants were disciplined for corrupt behavior, that figure dropped to 2 of every 10,000 during the 1970s and 1980s (though it may have risen in the 1990s, according to press reports). Indictments of public officials become lead stories in newspapers.

Corruption in Japan is also reduced by the competitive process under which companies work together in associations, pushing up proposals that eventually are backed by the consensus of member before being taken to the advisory councils of MITI (Ouchi 1984). Careful restraint, mutual scrutiny, and a devotion to $w a$ (harmony) prevents any one actor from gaining too much power.

The law enforcement agencies and the courts have dealt harshly with administrative corruption. The Board of Audit plays the primary role in investigating corruption and pointing out needed revisions of laws, regulations, and practices. Its audit reports are available to the public, allowing scrutiny by the press and the Diet. Investigative journalists have become increasingly active in exposing corruption, paying much more attention to the amakudari system in recent years (Inoguchi 1997; Johnson 1995, 223). They have been ably assisted in this regard by the work of official investigators, particularly those working in the 
Tokyo District Public Prosecutor's Office.

\section{Sierra Leone}

Sierra Leone, which once produced $\$ 500$ million worth of diamonds a year, currently exports less than $\$ 30$ million, according to records kept in Antwerp ("Diamond King” 2000, 52). A brutal civil war that has lasted since the early 1990 s partly accounts for this, but secondary corruption (when greed is uncontrolled by governance) remains the underlying cause. Unlike in Japan, government in Sierra Leone is so weak that bribery and extortion are not considered so much "scandalous" as "standard operating procedure." While the poor quality of political software in Sierra Leone might be blamed on the miserably paid and undisciplined civil servants, it is actually "those earning high salaries, primarily government ministers and senior civil servants, [who] have indulged in more fraud than junior workers or private citizens" (Kpundeh 1999, 214).

In countries suffering from secondary corruption, where senior officials are extremely corrupt, foreign aid may be useless or counterproductive. In a telling example of this, Kpundeh $(1993,242)$ reported that during the late $1980 \mathrm{~s}$, then-president Momoh deposited an estimated seven times the annual amount of funds obtained from the IMF in a personal bank account in Britain. Under the All People's Party, which ruled from 1968 to 1992, corruption became so institutionalized that nothing could prevent "the ravaging of the treasury" (Kpundeh 1999, 211). All the institutions of government were undermined during these years, including the judiciary, whose judges were forced or induced to rule in accord with governmental directives.

\section{Singapore: Using Politics to Change Culture}

Culture, often defined as "persistent patterns or systems of behavior and belief," can influence leaders' selection and implementation of decisions and policies (see Goodman 1967). To what extent, though, can leaders manipulate or change cul- ture by pursuing certain policies? Inasmuch as totalitarian rule in such countries as Cuba, Vietnam, and North Korea has relied upon coercion rather than persuasion, leaders' ability to permanently change the culture of their countries seems limited. In Singapore, however, the government has apparently been somewhat successful in significantly and permanently changing culture by implementing various policies and improving living conditions.

As late as the $1950 \mathrm{~s}$, prior to independence, the majority of Singapore's adult population lacked a primary-level education. Only about $20 \%$ were literate in English, reflecting the fact that their native language was Malay or a dialect of Chinese. Less than $7 \%$ were in professional, technical, or managerial occupations (Swee-Hock 1967). In 1958 , about $25 \%$ of the population lived below the poverty level. Underemployment, drug addiction, crime, gambling, and prostitution were widespread (Huat 1989). Families were large (with seven children, on average) and extended; men often took several wives. During the decade from 1947 to 1957 , the country's population grew at a rate of $4.4 \%$ annually, with a full $3.4 \%$ of the increase being attributable to live births (LePoer 1991, 73).

Singapore's living conditions are now very different, largely because of cultural engineering achieved through information dissemination, indoctrination or persuasion, incentives, disincentives, sanctions, and coercion (Quah and Quah 1989, 113; Tremewan 1994). "Probably nowhere else in the world are state policies to organize a country's people and to influence its values and attitudes so extensive and pervasive" (Fong, Huat, and May 1989, 129).

Singapore's capacity to reform its culture depended on the ability of its first post-colonial government to affect "cultural change" within the bureaucracy (Quah 1994, 205). To counter the bureaucratic corruption and apathy that had emerged during the colonial period, the Lee Kuan Yew government recruited the "best and brightest" to serve in the administration, improved salaries and working conditions, accelerated promotion for "high-flyers," reduced staffing, discouraged corruption, and worked to change the values of the civil servants. "The Singapore civil service today is a far cry from what it was during the colonial period because of changes in the basic assumptions or values that influence the behavior of its members today," noted Quah $(1994,215)$.

While Singapore can be considered a relatively authoritarian oneparty state, ordinary citizens, professionals, and businesses have been able to influence policy making, despite excessive controls. Policies have been generally pragmatic and flexible. Respect stems not only from the government's integrity, but also from its success in providing affordable housing, health care, public transportation, and education. Per capita income has risen from about U.S. $\$ 1,600$ in 1965 to nearly U.S. $\$ 33,000$ in 1997 , and unemployment and extreme poverty have been virtually eliminated (Huff 1999). Consequently, I disagree with Tremewan's argument that the government has "compelled compliance by constructing a powerful apparatus of state violence mediated through the law and the military" (1994, 232). Instead, I see public cooperation as resulting from the existing high quality of political software. This can best be illustrated in regard to birth control, where government officials employed a series of incentives and disincentives, including a national campaign to highlight the negative effects of a large family and the benefits of a two-child family, to reduce the fertility rate by almost $70 \%$ in about 20 years (Cheung 1990, 35).

Of course, increasing female educational and occupational opportunities may do more than anything else to lower birth rates. This certainly appears to have been the case in Hong Kong, where the fertility rate also declined below replacement level by 1980 , even though there was no official antinatalist policy. For this reason, it must be acknowledged that only part of Singapore's fertility decline can be attributed directly to governmental policies (Leete 1994, 817). Nevertheless, these policies probably had some effect between 1970 and 1990 in doubling the percentage of females aged 25 to 29 with a secondary or college education, increasing female participation 
in wage-earning employment by more than $20 \%$, raising the average age at which women first married by nearly three years, and doubling the percentage of unmarried females in the 30 to 34 year age group (Cheung 1990).

Although the consequences of low fertility in Singapore have been largely positive (more resources for children, greater educational opportunity, a rise in the status of daughters, and a higher standard of living), there have been problems. The country has had trouble dealing with chronic labor shortages, a growing demand by single people for apartments or rooms, and the need for more publicly funded elder care. Consequently, the government reversed its antinatalist policy during the 1980s, beginning by offering incentives for well-educated women to enlarge their families, and later including women generally. It has found turning back the cultural clock (e.g., suggesting arranged marriages) to be extremely difficult, however. The fertility rate has continued to drop from 2.8 in 1970 to 1.48 in 1999; and nearly $14 \%$ of women aged 40 to 44 are single, as against 9.2\% in 1990 ( $\mathrm{Ng} \mathrm{2000,1).}$ Whether the government will have more success with its effort to require adults to care for elderly and handicapped parents remains to be seen.

\section{Jamaica}

Jamaica, which gained independence from British rule in 1962 (three years earlier than Singapore and without comparable communal strife), has also attempted cultural engineering (see Human and Social Development Group 1997). The government has been particularly anxious to break the linkage between high teenage pregnancy rates $(40 \%)$, female-headed households $(40 \%)$, school drop-out and failure rates (one-third of those from poor households), unemployment $(15.4 \%)$, poverty (one-third of the population), and crime and violence. However, because of administrative weakness and corruption, it has been largely unsuccessful. It has also failed to generate much economic growth. As of 1995, annual GNP per capita was only about U.S. $\$ 1,500$.
One might expect Jamaica, with about the same population size and colonial experience, to be more politically elastic than Singapore inasmuch as it is less autocratic. If, as some believe, there is a strong relationship between political corruption and monopoly of power (see Klitgaard 1996), Singapore should be far more corrupt than Jamaica, which has maintained a vigorous two-party system. Why then, in reality, is the opposite true?

The answer, as I see it, has to do with the fact that primary or liberal democracy has taken a dysfunctional form in Jamaica. Both political parties regularly employ criminal gangs (occasionally supported by police or civil servants) to mobilize political support, distribute favors, and intimidate opponents. The civil service, the judicial system, and the police have lost citizens' respect as their effectiveness has been undermined by inadequate pay, training, and $\mathrm{ex}^{-}$ pertise, and even drug money (Hudson and Seyer 1989). Consequently, the Jamaican government has not been able to even attempt Singapore-style public housing, transportation, and urban planning programs. It has even failed to use its National Housing Trust Fund to promote desired social behavior by linking housing loans to the completion of secondary education and postponement of parenthood (Klak and Hey 1992).

Jamaica is, in some respects, a more politically exciting and culturally vibrant country than Singapore, which is notorious for its repression and paternalism (see Tremewan 1994), but Jamaica is also a much more troubled country. Talented and entrepreneurial Jamaicans, particularly those most essential for economic expansion, have far less incentive than Singaporeans to serve their state. Thus, Jamaica needs more secondary democracy (consensus-building politics); Singapore, more primary democracy (competitive politics). Indeed, each might learn from the other.

\section{Conclusion: Restoring the Professional Role}

I believe political elasticity theory enables both students and professors to meaningfully compare the progress of particular countries. For example, in chapter nine of my book (Werlin 1998), I compared Ghana and South Korea in an effort to answer the question of "Why authoritarianism in many African countries has failed to create developmental dynamics whereas the results of authoritarianism in East Asian countries like South Korea has been nearly the opposite?" (Kohli 1990, 398). In 1959, Ghana and South Korea had about the same per capita income; by 1995 , South Korea's per capita income (U.S. $\$ 13,000$ ) was more than 20 times higher than Ghana's (less than U.S. \$600). Using case studies to compare performance, I concluded that South Korea's success could be primarily attributed to its greater practice of secondary democracy, particularly its attempts to build the consensus essential for maintaining high-quality political software.

Similar comparisons of governmental efforts to meet the challenges of development should be encouraged. I therefore suggest three that might be presented to students.

\section{Mexico and Spain}

Mexico and Spain had comparable levels of per capita income and social welfare during the 1970 s (see, respectively, Wise 1998; Yruela and Sorrano del Rosa 1998). However, while the ordinary Mexican has not benefitted much (particularly in regard to housing, health, and education) from the government's moves toward economic liberalization, which have included accepting GATT and NAFTA membership, the ordinary Spaniard has benefitted substantially from Spain's association with the European Community. Evidence of this disparity comes from the fact that the rate of extreme poverty in Mexico is over four times that of Spain's.

\section{India and China}

World Bank statistics regarding the world's two most populous countries indicate that India's GDP per capita growth rate between 1965 and 1990 was about one-third that of 
China's $(1.9 \%$ versus $5.8 \%$ ). While India's economic growth rate has improved significantly since, the Indian government has been far less successful than has China's in reducing poverty and misery. An estimated one-third of the Indian population continues to live in desperate poverty, and the illiteracy rate remains very high (one-third for men; $60 \%$ for women over 15) (Unger 1999, 12). Meanwhile, "China at the close of the twentieth century was the fastest-growing economy in the world" (Goldman and MacFarquhar $1999,4)$. Less than $5 \%$ of China's population lives below the poverty line, and $75 \%$ have received enough education to be considered at least somewhat literate. Television has reached almost every household, as against about $10 \%$ in 1980 . Life expectancy is now a respectable 70 years of age, despite serious public health and environmental problems (Schell and Shambaugh 1999, xviii).

Why is it that, as Brooke Unger asked, "As India has become democratic, it has become more chaotic?" (1999, 16), while China has been fairly successful in its efforts "to combine a market economy with the centralized Leninist party-state" (Goldman and MacFarquhar 1999, 4). These considerations suggest the usefulness of comparing India and China to test the relationship of economic globalization to democratization and administrative effectiveness.

\section{Nigeria and Indonesia}

Despite decades of authoritarian misrule and corruption, Indonesia has made much greater economic and social progress than has Nigeria (see Bevan, Collier, and Gunning 1999). Whereas Indonesia's per capita GDP was below that of Nigeria's in 1965, it was three times that of Nigeria's in 1990 (Lewis 1994, 10).

Programs to improve health services, education, agricultural production, manufacturing, and family planning have been far more successful in Indonesia than in Nigeria. While both countries have benefited from oil wealth, Indonesia has clearly used it more effectively than Nigeria. Both countries have experienced relatively successful political transitions in the last few years, caused by political tension in Nigeria and an economic downfall in Indonesia. Yet, considering the remarkable socioeconomic progress in Indonesia, I believe that there is less likelihood of sustained political chaos in Indonesia (even recognizing what has happened in East Timor, Aceh, and the Moluccas) than in Nigeria. After all, it is easier to do business in Indonesia than Nigeria. But students should be encouraged to challenge this conclusion.

In doing the comparisons here suggested, students should be reminded that developing the political capacity to promote growth is more important than economic growth by itself, that sustainable economic growth requires an improvement in the quality of life, and that a government's ability to promote development rests on its ability to promote an "enabling environment," which can be fostered but not dictated. While each student will eventually evolve his or her own conceptualization of reality, I can only hope that research grounded in political elasticity theory will facilitate this process.

\section{References}

Al-Sayyid, Mustapha K. 1993. "A Civil Society in Egypt." The Middle East Joumal 47(2): 228-42.

Bates, Robert H. 1996. "The Death of Comparative Politics." APSA-CP Newsletter $7(2): 1-2$.

Bevan, David L., Paul Collier, and Jan Willem Gunning. 1999. Nigeria and Indonesia: The Political Economy of Poverty, Equity, and Growth. Washington, DC: The World Bank and Oxford University Press.

Campbell, John C. 1989. "Democracy and Bureaucracy in Japan." In Democracy in Japan, ed. Takeshi Ishida and Ellis S. Krauss. Pittsburgh: University of Pittsburgh Press.

Chetwynd, Eric, and Mohamed M. Samaan. 1984. Egypt, Basic Village Services. Washington, DC: U.S. Agency for International Development.

Cheung, Paul P.L. 1990. "Micro-Consequences of Low Fertility in Singapore." AsiaPacific Population Journal 5(4): 35-46.

Davies, H.W.E. 1988. "The Control of Development in the Netherlands." Town Planning Review 59:207-20.

"Diamond Kings." 2000. The Economist, January $29,46,52$.

Flynn, Robert. 1986. "The Mediation of Bureaucratic-Professional Influence: Decentralization in Dutch Housing Policy." Political Studies 34:606-19.
Fong, Pang Eng, Tan Chwee-Huat, and Chen Soo May. 1989. "The Management of People." In The Management of Success: The Moulding of Modern Singapore, ed. Kermiel S. Sandhu and Paul Wheatley. Singapore: Institute of Southeast Asian Studies.

Goldman, Merle, and Roderick MacFarquhar. 1999. "Declining Economy, Declining Party-State." In The Paradox of China's Post-Mao Reforms, ed. Merle Goldman and Roderick MacFarquhar. Cambridge, MA: Harvard University Press.

Goodman, Mary Ellen, 1967. The Individual and Culture. Homewood, IL: Dorsey.

Hamnett, Steve. 1985. "Political Framework and Developmental Objectives of PostWar Dutch Planning." In Public Planning in the Netherlands, ed. Ashok K. Dutt and Frank J. Costa. Oxford: Oxford University Press.

Huat, Chua Beng. 1989. "The Business of Living in Singapore." In The Management of Success: The Moulding of Modern Singapore, ed. Kernial S. Sandhu and Paul Wheatley. Singapore: Institute of Southeast Asian Studies.

Hudson, Rex A., and Daniel J. Seyers, eds. 1989. "Jamaica." In Islands of the Commonwealth: A Regional Study. Washington,
DC: Federal Research Division, Library of Congress.

Huff, W.G. 1999. "Turning the Corner in Singapore's Developmental State?" Asian Survey 33(2): 214-42.

Hull, Adrian P. 1999. "Comparative Political Science: An Inventory and Assessment Since the 1980s." PS: Political Science and Politics 32(March): 117-24.

Human and Social Development Group. 1997. Violence and Urban Poverty in Jamaica: Breaking the Cycle. Washington, DC: World Bank.

Iga, Mamoru, and Morton Auerbach. 1977. "Political Corruption and Social Structure in Japan." Asian Survey 17(6): 556-61.

Inoguchi, Takashi. 1997. "Japanese Bureaucracy: Coping with New Challenges." In Japanese Politics Today, ed. Pumendra Jain and Takashi Inoguchi. New York: S1. Martin's Press.

Johnson, Chalmers. 1995. Japan: Who Gov erns? New York: W.W. Norton.

Kienle, Eberhard. 1998. "More than a Response to Islamism: The Political Deliberalization of Egypt in the 1990s." Middle East Journal 52(2): 219-35.

Klak, Thomas H., and Jeanne K. Hey. 1992. "Gender and State Bias in Jamaican Housing Programs." World Development 20(2): 213-27.

Klitgaard, Robert. 1996. "Bolivia: Healing 
Sick Institutions in La Paz." In Governance and the Economy in Africa: Tools for Analysis and Reform of Comuption, ed. Patrick Meagher. College Park: Center for Institutional Reform and the Informal Sector, University of Maryland.

Koh, B.C. 1989. Japan's Administrative Elite. Berkeley and Los Angeles: University of California Press.

Kohli, Atul. 1990. Democracy and Discontent: India's Growing Crisis of Governability. Cambridge, MA: Harvard University Press.

Kpundeh, Sahr J. 1993. "Prospects in Contemporary Sierra Leone." Corruption and Reform 7(3): 237-47.

- 1999. "The Fight Against Corruption in Sierra Leone." In Curbing Corruption: Toward a Model for Building National Integrity, ed. Rick Stapenhurst and Sahr J. Kpundeh. Washington, DC: World Bank EDI Development Studies.

Leete, Richard. 1994. "The Continuing Flight from Marriage and Parenthood among the Overseas Chinese in East and Southeast Asia." Population and Development Review 20(4): 811-29.

LePoer, Barbara Leitch, ed. 1991. Singapore, a Country Study. Washington, DC: Federal Research Division, Library of Congress.

Lewis, Peter M. 1994. "State Structure, Elite Cohesion, and Economic Change: Nigeria and Indonesia Compared." Presented at the Annual Meeting of the American Political Science Association, New York.

Lichbach, Mark Irving, and Alan S. Zuckerman. 1997. "Research Traditions and Theory in Comparative Polities: An Introduction." In Comparative Politics: Rationality, Culture, and Structure, ed. Mark I. Lichbach and Alan S. Zuckerman. Cambridge: Cambridge University Press.

MacDougell, Terry E. 1988. "The Lockheed
Scandal and the High Cost of Politics in Japan." In The Politics of Scandal: Power and Process in Liberal Democracies, ed. Andrei S. Markovits and Mark Silverstein. New York: Holmes \& Meier.

Morris, A.E.J. 1985. "Historical Roots of Dutch City Planning and Urban Form." In Public Planning in the Netherlands, ed. Ashok K. Dutt and Frank J. Costa. Oxford: Oxford University Press.

Netherlands Scientific Council. 1990. Institutions and Cities: The Dutch Experience. The Hague: Netherlands Scientific Council for Government Policy.

$\mathrm{Ng}$, Irene. 2000. "Government Looks to Nongrads to Boost Births." The Straits Times Weekly Edition, March 18, 1.

Ouchi, William G. 1984. The M-Form Society. New York: Avon Books.

Quah, Jon S.T. 1994. "Cultural Change in the Singapore Civil Service." In Civil Service Reform in Latin America and the Caribbean: Proceedings of a Conference, eds. Shahid A. Chaudry, Gary J. Reid, and Waleed H. Malik. Washington, DC: The World Bank.

_-, and Stella R. Quah. 1989. "Government Intervention." In The Management of Success: The Moulding of Modern Singapore, ed. Kerniel S. Sandhu and Paul Wheatley. Singapore: Institute of Southeast Asian Studies.

Schell, Orville, and David Shambaugh. 1999. "Introduction." In The China Reader: The Reform Era, ed. Orville Schell and David Shambaugh. New York: Vintage Books.

Swee-Hock, Saw. 1967. Singapore Population in Transition. Philadelphia: University of Pennsylvania Press.

Toonen, Theo A.J. 1987. "The Netherlands: A Decentralised State in a Welfare Society." West European Politics 10(1):108-27. -. 1996. "On the Administrative Condition of Public Administration in the Netherlands." West European Politics 19(3): 60932.

Tremewan, Christopher. 1994. The Political Economy of Social Control in Singapore. New York and London: Macmillan Press and St. Martin's Press.

Tschirgi, Dan. 1999. "Marginalized Violent Internal Conflict in the Age of Globalization: Mexico and Egypt." Arab Studies Quarterly 21(3): 13-33.

Unger, Brooke. 1999. "Survey of India and Pakistan: Creative Chaos." The Economist, May 22, 1-18.

van Wolferen, Karel. 1989. The Enigma of Japanese Power: People and Power in a Stateless Society. New York: Alfred A. Knopf.

Waldo, Dwight. 1980. The Enterprise of Public Administration. Novato, CA: Chandler \& Sharp.

Werlin, Herbert H. 1974. Governing an African City: A Study of Nairobi. New York: Africana.

- 1998. The Mysteries of Development: Studies Using Political Elasticity Theory. Lanham, MD: University Press of America.

Wise, Carol. 1998. "Introduction." In The Post-NAFTA Political Economy: Mexico and the Western Hemisphere, ed. Carol Wise. University Park: Pennsylvania State University Press.

Wolin, Sheldon S. 1960. Politics and Vision: Continuity and Innovation in Western Political Thought. Boston: Little, Brown.

Woodall, Brian. 1993. "The Logic of Collusive Action: The Political Roots of Japan's Dango System." Comparative Politics 25(3): 297-312.

Yruela, Manuel P., and Rafael Serrano del Rosa. 1998. "Contemporary Spanish Society: Social, Institutional and Cultural Change." In Contemporary Spain, ed. Teresa Lawlor and Mike Rigby. London: Longman. 